\title{
Intestinal microbial ecology and hematological parameters of broiler fed cassava waste pulp fermented with Acremonium charticola
}

\author{
Sugiharto Sugiharto, Turrini Yudiarti, Isroli Isroli, Endang Widiastuti and Fatan Dwi Putra \\ Department of Animal Science, Faculty of Animal and Agricultural Sciences, Diponegoro University, Semarang, \\ Central Java, Indonesia. \\ Corresponding author: Sugiharto Sugiharto, e-mail: sgh_undip@yahoo.co.id, \\ Co-authors: TY: tyudiarti@yahoo.co.id, II: isroliundip02@yahoo.com, EW: endwidia@yahoo.co.id, \\ FDP: fatandwiputra@gmail.com \\ Received: 29-10-2016, Accepted: 02-02-2017, Published online: 18-03-2017
}

doi: 10.14202/vetworld.2017.324-330 How to cite this article: Sugiharto S, Yudiarti T, Isroli I, Widiastuti E, Putra FD (2017) Intestinal microbial ecology and hematological parameters of broiler fed cassava waste pulp fermented with Acremonium charticola, Veterinary World, 10(3): 324-330.

\begin{abstract}
Aim: The aim of this study was to evaluate the effect of feeding Acremonium charticola-fermented cassava pulp (AC-FCP) on the intestinal microbial ecology and hematological indices of broiler chickens.

Materials and Methods: A total of 240 male Lohman day-old-chicks were randomly allotted to one of the four experimental diets including control diet, control diet + antimicrobials (neomycin; $300 \mathrm{mg} / \mathrm{kg}$ diet), diet containing AC-FCP $(16 \mathrm{~g} / 100 \mathrm{~g}$ diet) or diet containing AC-FCP + antimicrobials. At day 28, the birds from each pen were blood sampled, sacrificed and immediately the internal organs were removed and weighed. Digesta were obtained from the ileum and cecum.

Results: Birds fed AC-FCP had lower $(p<0.05)$ coliform bacteria count in the ileal digesta than birds fed control diet or control diet + antimicrobials. Butiric acid was higher $(\mathrm{p}<0.05)$ in the cecal content of birds fed AC-FCP than in other birds. Propionic acid was also higher in AC-FCP fed birds than in other birds although statistically not significant. The percentages of lymphocytes and heterophils were higher $(\mathrm{p}<0.05)$ and tended $(\mathrm{p}=0.07)$ to be lower, respectively, in broilers fed control diet than in other birds. The birds provided control diet had lower $(\mathrm{p}<0.05)$ heterophils to lymphocytes ratio compared to those receiving AC-FCP or AC-FCP + antimicrobials. Serum total protein and globulin were higher $(\mathrm{p}<0.01)$ in birds fed control diet or control diet + antimicrobials compared to AC-FCP or AC-FCP + antimicrobials fed birds. Serum albumin was lower $(\mathrm{p}<0.01)$ in AC-FCP birds than that in other birds. There was a tendency $(\mathrm{p}=0.09)$ that birds fed AC-FCP diet had lower total serum cholesterol than other birds.
\end{abstract}

Conclusion: Feeding AC-FCP has potential to improve the intestinal health and protect the birds from acute infections.

Keywords: Acremonium charticola, broiler, fermented cassava pulp, hematological profile, intestinal microbial ecosystem, probiotics.

\section{Introduction}

Following the withdrawal of antimicrobial agents as feed additives from broiler diets, the broiler industry is now dealing with increasingly problems related to intestinal microbial imbalance and impaired immune competence [1,2]. Several nutraceutical compounds have been proposed to replace the role of synthetic antimicrobials for broiler chickens, of which probiotics and antioxidants are the examples [2]. Recently, we have isolated the filamentous fungus Acremonium charticola (AC) from the Indonesian fermented dried cassava [3] and showed that the fungus had probiotic [4] and antioxidant potentials [4,5]. The fungus may, therefore, be exploited to exert health effects on broiler chickens. Apart from its

Copyright: Sugiharto, et al. Open Access. This article is distributed under the terms of the Creative Commons Attribution 4.0 International License (http://creativecommons.org/licenses/ by/4.0/), which permits unrestricted use, distribution, and reproduction in any medium, provided you give appropriate credit to the original author(s) and the source, provide a link to the Creative Commons license, and indicate if changes were made. The Creative Commons Public Domain Dedication waiver (http:// creativecommons.org/publicdomain/zero/1.0/) applies to the data made available in this article, unless otherwise stated. nutraceutical properties, AC has been reported to possess a fiber-degrading ability [4] that may be advantageous for lowering the fiber content of particular (unconventional) feed ingredients.

Due to global rise in the price of feed ingredients (for example maize), there is now a tendency in the poultry industry to move toward the use of alternative feed ingredients. Cassava pulp, which is a by-product of tapioca industry, has recently been used in broiler diets as an energy source. However, its utilization is limited due to the low and high contents of protein and fiber, respectively [6]. In the previous study, we fermented cassava pulp (FCP) with $\mathrm{AC}$ and subsequently included in broiler rations to partially replace maize in the diets. Indeed, feeding AC-FCP improved immune responses (indicated by the low heterophil to lymphocyte [H/L] and albumin to globulin $[\mathrm{A} / \mathrm{G}]$ ratio) and had no negative effects on the nutritional state and metabolic performance of broiler chickens [7]. In this study, AC-FCP was provided to broilers not only to reduce the proportion of maize in the diets but also to replace the role of synthetic antimicrobials for broiler chickens.

Taken together, the objective of this study was to evaluate the effect of feeding AC-FCP on the 
intestinal microbial ecology and hematological indices of broiler chickens.

\section{Materials and Methods \\ Ethical approval}

The present study was approved by the Animal Ethics Committee of Faculty of Animal and Agricultural Sciences, Diponegoro University.

\section{Fungi and starter preparation}

$\mathrm{AC}$ inoculum was prepared by retrieving the fungal culture (maintained on a potato-dextrose-agar [PDA; Merck KGaA, Darmstadt, Germany] and stored at $4^{\circ} \mathrm{C}$ ), streaking on PDA medium and incubating at $38^{\circ} \mathrm{C}$ for 2 days. After being dislodged from the PDA, the fungal mycelia was diluted in $200 \mathrm{ml}$ of sterilized distilled water and further used to prepare the fungal starter.

About $200 \mathrm{~g}$ of sterilized dry cassava pulp (87.5\% dry matter) was inoculated with the suspension of fungal mycelia and then thoroughly mixed. After aerobic incubation at room temperature for 4 days, the inoculation starter was enumerated based on the colony counting method. The fungal starter produced was eventually used to ferment the cassava pulp for the in vivo experiment.

\section{FCP preparation}

Fermentation of cassava pulp was carried out according to Sugiharto et al. [7] with some modifications. In brief, $10 \mathrm{~kg}$ of steamed cassava pulp was soaked with sterile water $(1: 1)$. The cassava pulp was inoculated with $110 \mathrm{~g} / \mathrm{kg}$ fungal starter $\left(3.6 \times 10^{10} \mathrm{cfu} / \mathrm{g}\right)$ and $41 \mathrm{~g} / \mathrm{kg}$ urea and then thoroughly mixed. The mixture was incubated for 4 days and turned every 2 days. The AC-FCP was sundried before use for the in vivo experiment. Proximate analysis showed that AC-FCP contained energy (based on Bolton [8] formula) of $2886 \mathrm{kcal} / \mathrm{kg}$ and crude protein (Kjeldahl method) $8.5 \%$.

\section{In vivo experiment}

A total of 240 male Lohman MB-202 day-oldchicks (body weight $=41.3 \pm 2.68 \mathrm{~g}$; mean \pm standard deviation) purchased from a local hatchery were placed in an open-sided naturally ventilated broiler house and randomly allotted to one of the four experimental diets, including control diet, control diet with antimicrobials (neomycin), diet containing AC-FCP or diet containing AC-FCP and antimicrobials. The diets were formulated to be isonitrogenous and isoenergy and meet the Indonesian National Standards for Broiler Feed [9] requirements for broilers (Table-1). The diets were fed ad libitum in mash form, and throughout the experimental period, the birds were reared in concrete floor pens with rice husk as bedding material equipped with round bottom feeder and manual drinker.

At day 28, birds from each pen were randomly selected for sampling after being deprived from feed for $8 \mathrm{~h}$. For hematological analysis, blood was obtained from the birds' wing veins and collected in ethylenediamine tetraacetic acid-containing vacutainers. The rest of the blood was collected in vacutainers containing no anticoagulant and allowed to clot for $2 \mathrm{~h}$ at room temperature. After centrifugation at $2000 \mathrm{rpm}$ for $15 \mathrm{~min}$, the serum was obtained and stored at $-20^{\circ} \mathrm{C}$ until serum biochemistry analysis. The same birds that were blood sampled were sacrificed after being weighed, and immediately the internal organs were removed and weighed. Digesta were aseptically obtained from the ileum and cecum for $\mathrm{pH}$ measurement and microbiological and short-chain fatty acids (SCFA) analyses.

Microbial counts in the intestinal digesta were determined as described by Engberg et al. [10] with few modifications. Total bacteria were counted on PDA after aerobic incubation at $38^{\circ} \mathrm{C}$ for $24 \mathrm{~h}$. Coliform bacteria and lactose-negative enterobacteria were enumerated on MacConkey agar following aerobic incubation at $38^{\circ} \mathrm{C}$ for $24 \mathrm{~h}$ as red and colorless colonies, respectively. Enterobacteria were the number of coliform bacteria and lactose-negative enterobacteria. Lactic acid bacteria (LAB) were enumerated on de Man, Rogosa and Sharpe agar after anaerobic incubation at $38^{\circ} \mathrm{C}$ for $48 \mathrm{~h}$. The concentration of SCFAs in the cecal contents was determined by gas chromatography under the conditions described by Sugiharto et al. [11].

The numbers of erythrocytes and leukocytes were measured based on the dilution flask method, and a Bürker chamber was employed to count corpuscles. The concentration of hemoglobin was determined by Sahli's method, and hematocrit values were estimated through the microhematocrit technique. The differential leukocytes of broilers were determined using a light microscope with an immersion lens. Coverslip technique was performed when preparing blood smears. $\mathrm{H} / \mathrm{L}$ ratio was determined by dividing the numbers of $\mathrm{H} / \mathrm{L}$. Serum total triglyceride was determined according to enzymatic colorimetric method using glycerol-3-phosphateoxidase (DiaSys Diagnostic System GmbH, Holzheim, Germany). Total cholesterol, high-density lipoprotein (HDL), and low-density lipoprotein (LDL) cholesterol were measured based on enzymatic colorimetric method with cholesterol oxidase/p-aminophenazone (DiaSys Diagnostic System GmbH, Holzheim, Germany). The enzymes of alanine aminotransferase (ALT) and aspartate aminotransferase (AST) were determined spectrophotometrically using a Reflotron system (Roche Diagnostics Corporation, Indianapolis, IN, USA). Total protein in the serum was assessed by photometric test based on the biuret method with the kit (total protein kit, DiaSys Diagnostic System GmbH, Holzheim, Germany) according to the manufacturer's instructions. Albumin in serum was measured by photometric test using bromocresol green (DiaSys Diagnostic System GmbH, Holzheim, Germany). Globulin was obtained by subtracting albumin values 
Table-1: Ingredients and composition (as-dry basis) of treatment diets.

\begin{tabular}{|c|c|c|c|c|}
\hline \multirow[t]{2}{*}{ Items ( $\%$, unless otherwise noted) } & \multicolumn{4}{|c|}{ Dietary treatments } \\
\hline & Control diet & Control diet+antimicrobials & AC-FCP & AC-FCP+antimicrobials \\
\hline Maize & 54.0 & 54.0 & 45.0 & 45.0 \\
\hline Soybean meal & 27.0 & 27.0 & 23.5 & 23.5 \\
\hline$A C-F C P$ & - & - & 16.0 & 16.0 \\
\hline Fish meal & 9.00 & 9.00 & 10.6 & 10.6 \\
\hline Rice bran & 6.75 & 6.75 & 1.25 & 1.25 \\
\hline Broken rice & 1.00 & 1.00 & 1.50 & 1.50 \\
\hline DL-methionine & 0.23 & 0.23 & 0.25 & 0.25 \\
\hline L-lysine & 0.06 & 0.06 & 0.15 & 0.15 \\
\hline Limestone & 1.01 & 1.01 & 0.80 & 0.80 \\
\hline Dicalcium phosphate & 0.20 & 0.20 & 0.20 & 0.20 \\
\hline Premi×1 & 0.50 & 0.50 & 0.50 & 0.50 \\
\hline $\mathrm{NaCl}$ & 0.25 & 0.25 & 0.25 & 0.25 \\
\hline Neomycin & - & 0.0003 & - & 0.0003 \\
\hline \multicolumn{5}{|l|}{ Calculated composition } \\
\hline Metabolizable energy $(\mathrm{kcal} / \mathrm{kg})^{2}$ & 2892 & 2892 & 2873 & 2873 \\
\hline Crude protein & 22.5 & 22.5 & 22.0 & 22.0 \\
\hline Crude fiber & 3.52 & 3.52 & 5.67 & 5.67 \\
\hline Calcium & 1.03 & 1.03 & 1.03 & 1.03 \\
\hline Phosphor & 0.56 & 0.56 & 0.54 & 0.54 \\
\hline Methionine & 0.66 & 0.66 & 0.66 & 0.66 \\
\hline Lysine & 1.43 & 1.43 & 1.43 & 1.43 \\
\hline
\end{tabular}

${ }^{1}$ Mineral-vitamin premix provided (per $\mathrm{kg}$ of diet) $\mathrm{Ca}-2.250 \mathrm{~g}, \mathrm{P}-0.625 \mathrm{~g}$, Fe $-3.570 \mathrm{mg}, \mathrm{Cu}-0.640 \mathrm{mg}$,

Mn - 5.285 mg, Zn - 0.003 mg, Co - 0.001 mg, Se - 0.013 mg, I - 0.016 mg, vitamin A - 375 IU, vitamin D - 150 IU, vitamin E $-0.080 \mathrm{mg},{ }^{2}$ Values were obtained based on the formula according to Bolton [8]. AC-FCP=Acremonium charticola-fermented cassava pulp

from total serum protein. A/G ratio was calculated by dividing albumin and globulin values.

\section{Data analysis}

The data were analyzed according to a completely randomized design by ANOVA using the General Linear Models Procedure in SAS (SAS Inst. Inc., Cary, NC, USA). Pen was treated as the experimental unit. Results are presented as least square means and standard error of the mean. Significant differences among dietary treatments were further analyzed with Duncan's multiple-range test. A significant level of $\mathrm{p} \leq 0.05$ was applied.

\section{Results}

\section{Intestinal microbial population}

The data of microbial population in the ileal and cecal digesta of broilers are presented in Table-2. Birds fed AC-FCP had lower $(p<0.05)$ coliform bacteria count in the ileal digesta when compared with the birds fed control diet or control diet + antimicrobials, but the significant difference was not observed when compared with those of fed AC-FCP + antimicrobials. The difference in coliform bacteria was not seen in the cecal digesta of broilers. There was no difference $(p>0.05)$ with regard to total bacteria, enterobacteria, lactose negative-enterobacteria, and $\mathrm{LAB}$ in the ileal and cecal digesta of broilers across the treatment groups.

\section{Concentrations of SCFAs in ceca}

The concentrations of SCFA in digesta from the ceca of broilers are presented in Table-3. Butiric acid was higher $(p<0.05)$ in the cecal digesta of birds fed AC-FCP than in the digesta from other birds. Accordingly, the concentration of propionic acid was higher in the digesta of AC-FCP birds than in other birds although it was not statistically significant. The significant difference was not observed for the concentration of acetic acid and the $\mathrm{pH}$ of digesta from ceca of broilers.

\section{Hematological and biochemical parameters}

The data of hematological and biochemical parameters of broilers are presented in Table- 4 . The percentages of lymphocytes and heterophils were higher $(\mathrm{p}<0.05)$ and tended $(\mathrm{p}=0.07)$ to be lower, respectively, in broilers fed control diet than in other birds. The birds provided control diet had lower $(p<0.05) H / L$ ratio as compared with those of fed AC-FCP or AC-FCP + antimicrobials. There was no difference $(p>0.05)$ in the numbers of hemoglobin, erythrocytes, hematocrit, mean corpuscular volume, mean corpuscular hemoglobin $(\mathrm{MCH}), \mathrm{MCH}$ concentration, and leukocytes as well as the proportion of eosinophils and monocytes in the blood of broiler chickens.

Serum total protein and globulin were higher $(p<0.01)$ in birds fed control diet or control diet + antimicrobials as compared to those of fed AC-FCP or AC-FCP + antimicrobials. Serum albumin was lower $(p<0.01)$ in AC-FCP birds than that in other birds. There was a tendency $(p=0.09)$ that birds fed AC-FCP diet had lower total cholesterol in the serum than other birds. No significant different was observed for the serum AST, ALT, total triglyceride, LDL, HDL and $\mathrm{A} / \mathrm{G}$ ratio of broilers. 
Table-2: Microbial population in the ileal and cecal digesta of broilers fed the treatment diets.

\begin{tabular}{|c|c|c|c|c|c|c|}
\hline \multirow[t]{2}{*}{ Items $(\log \mathrm{cfu} / \mathrm{g})$} & \multicolumn{4}{|c|}{ Dietary treatments } & \multirow[t]{2}{*}{ SEM } & \multirow[t]{2}{*}{ p value } \\
\hline & Control diet & et+antimicrobials A & AC-FCP & AC-FCP+antimicrobials & & \\
\hline \multicolumn{7}{|l|}{ Ileum } \\
\hline Total bacteria & 12.1 & 12.2 & 12.2 & 12.2 & 0.19 & 0.94 \\
\hline Enterobacteria & 6.71 & 6.67 & 6.35 & 6.39 & 0.17 & 0.35 \\
\hline Coliform bacteria & $6.61^{a}$ & $6.61^{a}$ & $5.95^{b}$ & $6.28^{\mathrm{ab}}$ & 0.16 & 0.03 \\
\hline $\begin{array}{l}\text { Lactose } \\
\text { negative-enterobacteria }\end{array}$ & 5.95 & 5.82 & 5.97 & 5.63 & 0.24 & 0.74 \\
\hline LAB & 8.44 & 8.60 & 8.28 & 8.29 & 0.13 & 0.27 \\
\hline \multicolumn{7}{|l|}{ Cecum } \\
\hline Total bacteria & 12.1 & 12.3 & 12.1 & 11.9 & 0.18 & 0.54 \\
\hline Enterobacteria & 6.53 & 6.46 & 6.55 & 6.41 & 0.08 & 0.61 \\
\hline Coliform bacteria & 6.40 & 6.33 & 6.38 & 6.25 & 0.08 & 0.56 \\
\hline $\begin{array}{l}\text { Lactose } \\
\text { negative-enterobacteria }\end{array}$ & 5.88 & 5.76 & 5.97 & 5.86 & 0.16 & 0.82 \\
\hline LAB & 8.46 & 8.46 & 8.44 & 8.29 & 0.12 & 0.69 \\
\hline
\end{tabular}

$a, b$ Means in a row with different superscripts are significantly different $(p \leq 0.05)$. AC-FCP=Acremonium

charticola-fermented cassava pulp, LAB=Lactic acid bacteria, SEM=Standard error of mean

Table-3: Concentrations of SCFA and pH of cecal digesta of broilers fed the treatment diets.

\begin{tabular}{|c|c|c|c|c|c|c|}
\hline \multirow[t]{2}{*}{ Items } & \multicolumn{4}{|c|}{ Dietary treatments } & \multirow[t]{2}{*}{ SEM } & \multirow[t]{2}{*}{ p value } \\
\hline & Control diet & Control diet+antimicrobials & AC-FCP & AC-FCP+antimicrobials & & \\
\hline Acetic acid $(\mathrm{mmol} / \mathrm{kg})$ & 27.4 & 44.6 & 37.2 & 47.5 & 9.07 & 0.34 \\
\hline Propionic acid (mmol/kg) & 10.6 & 10.3 & 19.0 & 13.4 & 2.81 & 0.12 \\
\hline Butiric acid (mmol/kg) & $4.39 a$ & $6.66^{\mathrm{ab}}$ & $10.5^{\mathrm{b}}$ & $4.77^{a}$ & 1.45 & 0.03 \\
\hline $\mathrm{pH}$ of ceca & 6.00 & 5.40 & 5.80 & 6.00 & 0.32 & 0.51 \\
\hline
\end{tabular}

$a, b$ Means in a row with different superscripts are significantly different $(p \leq 0.05)$. AC-FCP=Acremonium

charticola-fermented cassava pulp, SEM=Standard error of mean, SCFA=Short chain fatty acids

Table-4: Hematological and biochemical parameters of broilers fed the treatment diets.

\begin{tabular}{|c|c|c|c|c|c|c|}
\hline \multirow[t]{2}{*}{ Items } & \multicolumn{4}{|c|}{ Dietary treatments } & \multirow[t]{2}{*}{ SEM } & \multirow[t]{2}{*}{ p value } \\
\hline & $\begin{array}{c}\text { Control } \\
\text { diet }\end{array}$ & Control diet+antimicrobials & AC-FCP & AC-FCP+antimicrobials & & \\
\hline \multicolumn{7}{|l|}{ Hematological parameters } \\
\hline Hemoglobin $(\mathrm{g} / \mathrm{dL})$ & 6.92 & 6.65 & 7.40 & 7.10 & 0.54 & 0.77 \\
\hline Erythrocytes $\left(10^{12} / \mathrm{L}\right)$ & 2.67 & 2.50 & 2.82 & 2.49 & 0.21 & 0.57 \\
\hline Hematocrit (\%) & 20.2 & 19.5 & 22.0 & 20.8 & 1.68 & 0.72 \\
\hline $\mathrm{MCV}(\mathrm{fl})$ & 76.6 & 78.7 & 80.0 & 85.7 & 8.82 & 0.86 \\
\hline $\mathrm{MCH}(\mathrm{pg})$ & 26.2 & 26.8 & 26.9 & 29.3 & 2.94 & 0.86 \\
\hline $\mathrm{MCHC}(\mathrm{g} / \mathrm{dL})$ & 34.4 & 34.1 & 33.7 & 34.1 & 0.24 & 0.16 \\
\hline Leukocytes $\left(10^{9} / \mathrm{L}\right)$ & 16.4 & 17.4 & 10.9 & 14.5 & 2.63 & 0.29 \\
\hline Heterophils (\%) & 17.4 & 22.3 & 29.4 & 26.3 & 3.83 & 0.07 \\
\hline Eosinophils (\%) & 1.40 & 3.75 & 2.20 & 4.25 & 0.88 & 0.10 \\
\hline Lymphocytes (\%) & $73.6^{a}$ & $57.3^{\mathrm{b}}$ & $54.6^{b}$ & $55.4^{\mathrm{b}}$ & 5.59 & 0.05 \\
\hline Monocytes (\%) & 7.60 & 8.25 & 13.8 & 9.0 & 2.19 & 0.15 \\
\hline $\mathrm{H} / \mathrm{L}$ ratio & $0.24^{a}$ & $0.35^{\mathrm{ab}}$ & $0.54^{b}$ & $0.50^{b}$ & 0.09 & 0.05 \\
\hline \multicolumn{7}{|l|}{$\begin{array}{l}\text { Serum biochemical } \\
\text { parameters }\end{array}$} \\
\hline AST (U/L) & 280 & 239 & 249 & 207 & 22.8 & 0.20 \\
\hline ALT $(U / L)$ & 13.6 & 16.9 & 13.2 & 15.5 & 1.43 & 0.24 \\
\hline Total triglyceride $(\mathrm{g} / \mathrm{dL})$ & 47.2 & 43.6 & 39.2 & 47.4 & 6.72 & 0.80 \\
\hline Total cholesterol $(\mathrm{g} / \mathrm{dL})$ & 137 & 130 & 103 & 111 & 10.0 & 0.09 \\
\hline $\operatorname{LDL}(\mathrm{g} / \mathrm{dL})$ & 21.2 & 11.5 & 12.5 & 7.85 & 5.92 & 0.46 \\
\hline HDL (g/dL) & 100 & 111 & 89.3 & 96.4 & 9.87 & 0.17 \\
\hline Total protein $(\mathrm{g} / \mathrm{dL})$ & $3.08^{a}$ & $3.12^{\mathrm{a}}$ & $2.14^{\mathrm{c}}$ & $2.57^{b}$ & 0.12 & $<0.01$ \\
\hline Albumin (g/dL) & $0.94^{a}$ & $0.89^{a}$ & $0.59^{b}$ & $0.81^{a}$ & 0.06 & $<0.01$ \\
\hline Globulin $(\mathrm{g} / \mathrm{dL})$ & $2.15^{a}$ & $2.23^{a}$ & $1.55^{\mathrm{b}}$ & $1.76^{\mathrm{b}}$ & 0.09 & $<0.01$ \\
\hline $\mathrm{A} / \mathrm{G}$ ratio & 0.45 & 0.41 & 0.38 & 0.46 & 0.03 & 0.13 \\
\hline
\end{tabular}

$a, b$ Means in a row with different superscripts are significantly different $(p \leq 0.05)$. AC-FCP=Acremonium

charticola-fermented cassava pulp, $\mathrm{MCV}=$ Mean corpuscular volume, $\mathrm{MCH}=$ Mean corpuscular hemoglobin, $\mathrm{MCHC}=\mathrm{Mean}$ corpuscular hemoglobin concentration, $\mathrm{H} / \mathrm{L}$ ratio=Heterophils to lymphocytes ratio, AST=Aspartate transaminase,

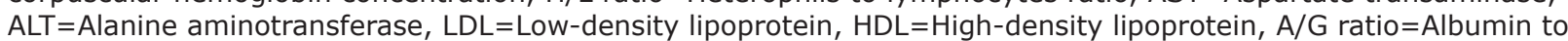
globulin ratio, SEM=Standard error of mean 


\section{Internal organ weight}

The data of internal organ weight of broilers are presented in Table-5. In general, no significant difference of internal organ weight of broilers was observed in this study.

\section{Discussion}

Fermentation of cassava pulp with the fungus AC was expected to produce a cheap functional feed that may be used to replace the role of synthetic antimicrobials for broiler chickens. Our present results showed that feeding AC-FCP reduced the number of coliform bacteria in the ileal digesta of broilers. This finding was in accordance with our previous study reporting the potential of AC in inhibiting the growth of Escherichia coli in vitro [4]. The mechanism through which AC reduced the population of coliform bacteria in the ileum of broilers remains unclear, but the capability of the fungus to produce some form of antibiotics and antimicrobial compounds that may impair the biological functions of the bacteria could be one mechanism [12]. Recent study reported that antioxidants are useful to modulate the cecal microflora and improve the immune competence of broiler chickens [13]. AC has been reported to possess antioxidant properties corresponding to ascorbic acid [5]. Hence, it is safe to assume that antioxidant activity of $\mathrm{AC}$ may also take part in lowering the number of coliform bacteria in the ileal contents of broilers. With regard to neomycin, this aminoglycoside antibiotic has been used to control the outbreak of $E$. coli infections in broilers [14]. However, our result showed no effect of neomycin on the population of coliform bacteria in the intestinal contents. The exact cause of this condition was not fully known, but the preparation of feed in mash form perhaps caused some of neomycin was not consumed by the chickens. As a consequence, the dose of neomycin was not enough to inhibit the proliferation of coliform bacteria in the intestine.

Volatile fatty acids (VFA) have been attributed to the health status of the gastrointestinal tract of chickens $[15,16]$. Of the VFA produced in cecum, butiric acid is of particular importance due to its nutritional properties for the intestinal epithelial cell. Butyric acid also has pathogen inhibitory effects in the intestine of broilers [16]. In addition to butyric acid, propionic acid has been reported to play an important role in inhibiting the colonization of birds by pathogenic bacteria $[15,16]$. In this study, birds fed AC-FCP produced higher butiric and propionic acids than other birds. It has been reported that the cecal concentration of VFA can be affected by several factors and that probiotics $[17,18]$, prebiotics and synbiotics [17] may elevate the concentration of VFA in the ceca of broilers. Taken together, probiotic activity of AC growing in the FCP seemed to be responsible for the increase in concentrations of butyric and propionic acids in the cecum of broilers. To date, the mechanism by which $\mathrm{AC}$ increased the concentration of butyric and propionic acids is not fully understood, but Meimandipour et al. [16] suggested that probiotic microorganisms may elevate the population of anaerobic bacteria responsible for producing butyric and propionic acids in the cecum of broilers. The increased concentration of butyric acid was, however, not seen in birds that received diet containing $\mathrm{AC}-\mathrm{FCP}+$ antimicrobials. In such case, neomycin may interrupt the balance of cecal microflora [19] resulting in reduced butyrate production. However, this inference should be interpreted with caution as most aminoglycoside antibiotics including neomycin are mostly ineffective against anaerobic bacteria such as butyric acid-producing bacteria in the cecum.

In this study, the proportion of lymphocytes was higher in broilers fed the control diet (without antimicrobials) than in birds fed AC-FCP or diets with antimicrobials. Indeed, the percentage of lymphocytes in control birds was higher than the standard of lymphocytes in chickens $(63 \%,[20])$. This condition may indicate that control birds experienced infection, as Ogunleye et al. [21] suggested that the increased numbers of lymphocytes (lymphocytosis) can be an indicator of acute infection and internal stress in chickens. Concomitant with the latter authors, Dudek and Bednarek [22] reported that the consecutive injection with $E$. coli lipopolysaccharides (LPS) resulted

Table-5: Internal organ weight of broilers fed the treatment diets.

\begin{tabular}{|c|c|c|c|c|c|c|}
\hline \multirow[t]{2}{*}{ Items ( $\%$ body weight) } & \multicolumn{4}{|c|}{ Dietary treatments } & \multirow[t]{2}{*}{ SEM } & \multirow[t]{2}{*}{ p value } \\
\hline & $\begin{array}{c}\text { Control } \\
\text { diet }\end{array}$ & Control diet+antimicrobials & AC-FCP & AC-FCP+antimicrobials & & \\
\hline Spleen & 0.12 & 0.20 & 0.16 & 0.17 & 0.05 & 0.68 \\
\hline Thymus & 0.21 & 0.28 & 0.25 & 0.26 & 0.03 & 0.40 \\
\hline Bursa of fabricius & 0.23 & 0.25 & 0.28 & 0.27 & 0.04 & 0.72 \\
\hline Liver & 2.93 & 2.97 & 2.74 & 2.65 & 0.16 & 0.43 \\
\hline Giblets $^{1}$ & 6.57 & 6.82 & 5.95 & 5.94 & 0.32 & 0.12 \\
\hline Duodenum & 1.22 & 1.30 & 1.34 & 0.86 & 0.16 & 0.18 \\
\hline Jejunum & 2.09 & 2.06 & 1.74 & 1.85 & 0.23 & 0.67 \\
\hline Ileum & 1.46 & 1.79 & 1.42 & 1.40 & 0.16 & 0.28 \\
\hline Ceca & 0.61 & 0.53 & 0.40 & 0.65 & 0.09 & 0.23 \\
\hline
\end{tabular}

${ }^{1}$ Giblets: Heart, gizzard and liver, AC-FCP=Acremonium charticola-fermented cassava pulp, BW=Body weight, $\mathrm{SEM}=$ Standard error of mean 
in lymphocytosis in pigeons. In this study, the concentration of globulin was higher in the serum of control birds when compared especially with the birds fed AC-FCP. Sharma et al. [23] previously reported an increased globulin concentration in the group of broilers infected with E. coli $\mathrm{O} 78$ as compared with uninfected broilers. The increased globulin in the present study may therefore further support our inference that control birds suffered from infection. The proportion of heterophils tended to be lower in control birds than in birds receiving AC-FCP or diets with antimicrobials in the current study. The heterophils in control birds were by far lower from the standard of heterophils in chickens $(30.1 \%$, [20]). It has been reported in pigeons that infection (consecutive injection with $E$. coli LPS) resulted in decreased number of heterophils (heteropenia) [22]. The latter authors further suggested that acute infection may increase migration of most heterophils from circulation into tissues resulting in decreased proportion of heterophils in the blood. $\mathrm{H} / \mathrm{L}$ ratio has long been used to indicate mild to moderate stress in poultry $[7,24]$. In this study, $\mathrm{H} / \mathrm{L}$ ratio was lower in birds fed control diet as compared with other birds. However, it is difficult to infer that control birds had lower level of stress than other birds as Müller et al. [25] suggested that severe stress (e.g., due to acute infections) may cause heteropenia and lymphocytosis in the periphery resulting in low $\mathrm{H} / \mathrm{L}$ ratio. Overall, from the microbiological and hematological data, it can be suggested that feeding AC-FCP may be beneficial for broilers in preventing the infection by pathogens. This suggestion was supported by Engberg et al. [26] at which fermented feed protected the chickens from E. coli, Salmonella and Campylobacter infections.

It has been reported that probiotics can lower total cholesterol level in the serum of broiler chickens [27]. In accordance with this, there was a clear tendency in the present study that birds receiving AC-FCP had lower total cholesterol level in the serum compared with other birds. Apart from the benefit effects of AC-FCP to broilers as mentioned above, feeding such diet should be conducted with caution as it could decrease total protein and albumin concentrations in the blood of broilers. In the preparation of AC-FCP, urea was used to increase the crude protein content of AC-FCP. Perhaps, some of the crude protein derived from urea could not be utilized properly by the chickens resulting in lower level of total protein and albumin in the serum of AC-FCP fed birds [28]. However, the decreased level of blood protein and albumin did not cause adverse effect on the internal organ development in this study.

\section{Conclusions}

It can be concluded from the present study that inclusion of AC-FCP in broiler diets was potential to improve the intestinal health and protect the birds from acute infections. Hence, AC-FCP can be a functional feed that may be used to replace the role of synthetic antimicrobials for broiler chickens.

\section{Authors' Contributions}

SS designed the study, analyzed the results, drafted and revised the manuscript. TY, II, EW and FDP carried the animal experiment and performed the laboratory work. All authors read and approved the final manuscript.

\section{Acknowledgments}

The study was fully funded by Diponegoro University through Non-Tax State Revenue (PNBP) No: SP DIPA - 042.01.2.400898/2016, December 07, 2015.

\section{Competing Interests}

The authors declare that they have no competing interests.

\section{References}

1. Huyghebaert, G., Ducatelle, R. and Van Immerseel, F. (2011) An update on alternatives to antimicrobial growth promoters for broilers. Vet. J., 187: 182-188.

2. Sugiharto, S. (2016) Role of nutraceuticals in gut health and growth performance of poultry. J. Saudi Soc. Agric. Sci., 15: 99-111.

3. Yudiarti, T. and Sugiharto, S. (2016) A novel filamentous fungus Acremonium charticola isolated from gathot (an Indonesian fermented dried cassava). Int. Food Res. J., 23(3): 1351-1354

4. Sugiharto, S., Yudiarti, T. and Isroli, I. (2015) Functional properties of filamentous fungi isolated from the Indonesian fermented dried cassava, with particular application on poultry. Mycobiology, 43(4): 415-422.

5. Sugiharto, S., Yudiarti, T. and Isroli, I. (2016) Assay of antioxidant potential of two filamentous fungi isolated from the Indonesian fermented dried cassava. Antioxidants, 5: 6 .

6. Khempaka, S., Molee, W. and Guillaume, M. (2009) Dried cassava pulp as an alternative feedstuff for broilers: Effect on growth performance, carcass traits, digestive organs, and nutrient digestibility. J. Appl. Poult. Res., 18: 487-493.

7. Sugiharto, S., Yudiarti, T. and Isroli, I. (2016) Haematological and biochemical parameters of broilers fed cassava pulp fermented with filamentous fungi isolated from the Indonesian fermented dried cassava. Livest. Res. Rural Dev., 28: 1-6.

8. Bolton, W. (1967) Poultry Nutrition. MAFF Bulletin No.174. HMSO, London.

9. SNI (Indonesian National Standard). (2006) Standard for Broiler Feed (SNI 01-3930-2006). National Standardization Agency of Indonesia, Jakarta, Indonesia.

10. Engberg, R.M., Hedemann, M.S., Steenfeldt, S. and Jensen, B.B. (2004) Influence of whole wheat and xylanase on broiler performance and microbial composition and activity in the digestive tract. Poult. Sci., 83: 925-938.

11. Sugiharto, S., Lauridsen, C. and Jensen, B.B. (2015) Gastrointestinal ecosystem and immunological responses in $E$. coli challenged pigs after weaning fed liquid diets containing whey permeate fermented with different lactic acid bacteria. Anim. Feed Sci. Technol., 207: 278-282.

12. Xu, L., Meng, W., Cao, C., Wang, J., Shan, W. and Wang, Q. (2015) Antibacterial and antifungal compounds from marine fungi. Mar. Drugs, 13: 3479-3513.

13. Khazaei, R., Esmailzadeh, L., Seidavi, A. and Simões, J. (2017) Comparison between rosemary and commercial antioxidant blend on performance, caecal coliform flora and immunity in broiler chickens fed with diets containing different levels of poultry fat. J. Appl. Anim. Res., 45(1): 263-267. 
14. Agunos, A., Léger, D. and Carson, C. (2012) Review of antimicrobial therapy of selected bacterial diseases in broiler chickens in Canada. Can. Vet. J., 53: 1289-1300.

15. Kubena, L.F., Bailey, R.H., Byrd, J.A., Young, C.R., Corrier, D.E., Stanker, L.H. and Rottinghaus, G.E. (2001) Cecal volatile fatty acids and broiler chick susceptibility to Salmonella Typhimurium colonization as affected by aflatoxins and T-2 toxin. Poult. Sci., 80: 411-417.

16. Meimandipour, A., Shuhaimi, M., Soleimani, A.F., Azhar, K., Hair-Bejo, M., Kabeir, B.M., Javanmard, A., Anas, M. and Yazid, A.M. (2010) Selected microbial groups and short-chain fatty acids profile in a simulated chicken cecum supplemented with two strains of Lactobacillus. Poult. Sci., 89: 470-476.

17. Mookiah, S., Sieo, C.C., Ramasamy, K., Abdullah, N. and Ho, Y.W. (2014) Effects of dietary prebiotics, probiotic and synbiotics on performance, caecal bacterial populations and caecal fermentation concentrations of broiler chickens. J. Sci. Food Agric., 94(2): 341-348.

18. Mountzouris, K.C., Palamidi, I., Tsirtsikos, P., Mohnl, M., Schatzmayr, G. and Fegeros, K. (2014) Effect of dietary inclusion level of a multi-species probiotic on broiler performance and two biomarkers of their caecal ecology. Anim. Prod. Sci., 55(4): 484-493.

19. Arabi, Y., Dimock, F., Burdon, D.W., AlexanderWilliams, J. and Keighley, M.R.B. (1979) Influence of neomycin and metronidazole on colonic microflora of volunteers. J. Antimicrob. Chemother., 5(5): 531-537.

20. Davis, A.K., Maney, D.L. and Maerz, J.C. (2008) The use of leukocyte profiles to measure stress in vertebrates: A review for ecologists. Funct. Ecol., 22(20): 760-772.

21. Ogunleye, A.O., Ajuwape, A.T.P. and Adetosoye, A.I.
(2009) Hematological changes in Salmonella Paratyphi A infected pullets. Rev. Élev. Méd. Vét. Pays Trop., 62(1): 23-26.

22. Dudek, K. and Bednarek, D. (2011) Cellular immune response of pigeons in the conditions of endotoxin fever and pyrogenic tolerance. Pol. J. Vet. Sci., 14(1): 127-133.

23. Sharma, V., Jakhar, K.K., Nehra, V. and Kumar, S. (2015) Biochemical studies in experimentally Escherichia coli infected broiler chicken supplemented with neem (Azadirachta indica) leaf extract. Vet. World, 8(11): 1340-1345.

24. Sugiharto, S., Yudiarti, T. and Isroli, I. (2016) Performances and haematological profile of broilers fed fermented dried cassava (Manihot esculenta Crantz). Trop. Anim. Health Prod., 48: 1337-1341.

25. Müller, C., Jenni-Eiermann, S. and Jenni, L. (2011) Heterophils/lymphocytes-ratio and circulating corticosterone do not indicate the same stress imposed on Eurasian kestrel nestlings. Funct. Ecol., 25: 566-576.

26. Engberg, R.M., Hammershøj, M., Johansen, N.F., Abousekken, M.S., Steenfeldt, S. and Jensen, B.B. (2009) Fermented feed for laying hens: Effects on egg production, egg quality, plumage condition and composition and activity of the intestinal microflora. Br. Poult. Sci., 50(2): 228-239.

27. Alkhalf, A., Alhaj, M. and Al-Homidan, I. (2010) Influence of probiotic supplementation on blood parameters and growth performance in broiler chickens. Saudi J. Biol. Sci., 17: 219-225.

28. Chowdhury, S.D., Roy, C.R. and Sarker, A.K. (1996) Urea in poultry nutrition - Review. Asian-Australas J. Anim. Sci., 9(3): 241-245.

$* * * * * * * *$ 